\title{
Greenhouse Gas Emissions from Cotton Field under Different Irrigation Methods and Fertilization Regimes in Arid Northwestern China
}

\author{
Jie Wu, ${ }^{1}$ Wei Guo, ${ }^{1}$ Jinfei Feng, ${ }^{1}$ Lanhai Li, ${ }^{2}$ Haishui Yang, ${ }^{1}$ \\ Xiaohua Wang, ${ }^{1}$ and Xinmin Bian ${ }^{1}$ \\ ${ }^{1}$ College of Agriculture, Nanjing Agricultural University, Nanjing 210095, China \\ ${ }^{2}$ State Key Laboratory of Desert and Oasis Ecology, Xinjiang Institute of Ecology and Geography, Chinese Academy of Sciences, \\ Xinjiang 830011, China
}

Correspondence should be addressed to Xinmin Bian; bxmnau@163.com

Received 19 February 2014; Revised 26 June 2014; Accepted 27 June 2014; Published 16 July 2014

Academic Editor: Antonio M. De Ron

Copyright (C) 2014 Jie Wu et al. This is an open access article distributed under the Creative Commons Attribution License, which permits unrestricted use, distribution, and reproduction in any medium, provided the original work is properly cited.

Drip irrigation is broadly extended in order to save water in the arid cotton production region of China. Biochar is thought to be a useful soil amendment to reduce greenhouse gas (GHG) emissions. Here, a field study was conducted to compare the emissions of nitrous oxide $\left(\mathrm{N}_{2} \mathrm{O}\right)$ and methane $\left(\mathrm{CH}_{4}\right)$ under different irrigation methods (drip irrigation (D) and furrow irrigation (F)) and fertilization regimes (conventional fertilization $(\mathrm{C})$ and conventional fertilization + biochar (B)) during the cotton growth season. The accumulated $\mathrm{N}_{2} \mathrm{O}$ emissions were significantly lower with $\mathrm{FB}, \mathrm{DC}$, and DB than with FC by $28.8 \%$, $36.1 \%$, and $37.6 \%$, while accumulated $\mathrm{CH}_{4}$ uptake was $264.5 \%, 226.7 \%$, and $154.2 \%$ higher with DC, DB, and FC than that with FB, respectively. Irrigation methods showed a significant effect on total global warming potential (GWP) and yield-scaled GWP $(P<0.01)$. DC and DB showed higher cotton yield, water use efficiency (WUE), and lower yield-scaled GWP, as compared with FC and FB. This suggests that in northwestern China mulched-drip irrigation should be a better approach to increase cotton yield with depressed GHG. In addition, biochar addition increased $\mathrm{CH}_{4}$ emissions while it decreased $\mathrm{N}_{2} \mathrm{O}$ emissions.

\section{Introduction}

Crop cultivation stimulates greenhouse gas (GHG) emissions from soil to the atmosphere from agricultural practices such as irrigation and fertilization, which in turn influences the biogeochemical process of carbon and nitrogen $(\mathrm{N})$ in the soil. The emissions of GHG from crop land have been estimated to account for $13.5 \%$ of the anthropogenic emissions worldwide [1]. How to reduce GHG emissions from agricultural practices without yield loss is an urgent task for crop production. Improving the cropping practices is a recommended strategy to mitigate greenhouse gas emissions from agricultural soil [1]. However, this strategy is highly dependent on the crops, since the cropping practices varied with crop species [2]. Cotton is one of the major cash crops delivering natural fibers to textile industries around the world. Globally, the harvested area of seed cotton is 32 million ha in 2010 [3]. Considerable field experiments have documented large amount of $\mathrm{N}_{2} \mathrm{O}$ emitted from cotton field due to high $\mathrm{N}$ fertilizer input and immoderate irrigation [46].

Soil moisture is one of the key factors affecting GHG production in agricultural soil. An optimal irrigation can reduce GHG emissions by regulating the $\mathrm{N}$ and carbon turnover process in soil via manipulating soil moisture. Most of the cotton production is situated in the semiarid or arid areas, where water-saving irrigation is a key issue for the cotton cultivation. Drip irrigation is one of the watersaving irrigation approaches broadly extended in semiarid or arid regions, since it can reduce surface evaporation, surface runoff, and deep percolation [7]. Water and mineral $\mathrm{N}$ fertilizer are directly supplied to the crop root zone through drip irrigation system to adapt to the crop requirements, hence improving the water and $\mathrm{N}$ use efficiency. Therefore, 
drip irrigation may have a large influence on the nitrogen and carbon turnover in soil and reduce the $\mathrm{N}$ fertilizerinduced $\mathrm{N}_{2} \mathrm{O}$ or carbon-related greenhouse gas (e.g., $\mathrm{CH}_{4}$ ) production, in relation to conventional furrow irrigation. For instance, several studies showed that drip irrigation significantly decreased the $\mathrm{N}_{2} \mathrm{O}$ emission from tomato and melon field, as compared with furrow irrigation [8-10]. However, the $\mathrm{N}$ fertilizer application rate is much higher in cotton cultivation than that in the aforementioned crops. The $\mathrm{N}$ fertilizer application rate is approximately $300 \mathrm{~kg} \mathrm{~N} \mathrm{ha}^{-1}$ in cotton production area of China, which is nearly two times higher than that in previous studies (120-175 $\left.\mathrm{kg} \mathrm{N} \mathrm{ha}^{-1}\right)[8,9]$. Thus, it is still unknown what the impact of drip irrigation would be on $\mathrm{N}_{2} \mathrm{O}$ emission under high $\mathrm{N}$ fertilizer application conditions.

Biochar is the byproduct of biomass pyrolysis, one of the technologies used to produce bioenergy. It has been suggested that biochar can be a useful soil amendment to improve soil physiochemical properties and crop yield, as well as to increase soil carbon storage and reduce GHG emissions [11-13]. Biochar addition could mitigate or inhibit $\mathrm{N}_{2} \mathrm{O}$ emission in most studies for increased adsorption of $\mathrm{NH}_{4}{ }^{+}$or changes in $\mathrm{pH}$ that alter the $\mathrm{N}_{2} \mathrm{O}$-to- $\mathrm{N}_{2}$ ratio during denitrification [14-16]. However, the effects of biochar on $\mathrm{CH}_{4}$ emissions have yet been inconsistent. Previous study showed that biochar addition to the upland soil increased $\mathrm{CH}_{4}$ emissions by 37\% [17]. On the other hand, $\mathrm{CH}_{4}$ uptake increased in some studies after biochar additions [18, 19]. The results for the observed changes in $\mathrm{CH}_{4}$ emissions may contradictorily depend on soil water content, soil type, and biochar type. Till now, few data are available to support these conclusions on the field scale especially for uplands.

Drip irrigation with plastic film mulching is widely recommended as a replacement of the traditional furrow irrigation, because seasonal shortage of irrigation water and low temperature have become critical factors limiting the productivity of cotton crop in this area. However, only a few studies investigated the characteristics of $\mathrm{CO}_{2}, \mathrm{~N}_{2} \mathrm{O}$, and $\mathrm{CH}_{4}$ emissions from cotton field under drip irrigation in China [20-22]. To our knowledge, there are no published field studies on the effect of biochar addition on GHG emissions from cotton field. Thus, the objectives of this study are to (a) investigate the characteristics of $\mathrm{N}_{2} \mathrm{O}$ and $\mathrm{CH}_{4}$ emissions from cotton field under different irrigation methods and fertilization regimes and (b) compare the integrated effects of different irrigation methods and fertilization regimes on the GHG emissions.

\section{Materials and Methods}

2.1. The Study Site. A field experiment was carried out at the experimental farm of Shihezi University in Xinjiang Province $\left(45^{\circ} 19^{\prime} \mathrm{N}, 116^{\circ} 34^{\prime} \mathrm{E}, 433-437 \mathrm{~m}\right.$ in elevation), which locates in the primary cotton production region of China. This region has a dry continental climate with mean annual temperature of $8^{\circ} \mathrm{C}$ and precipitation of $150 \mathrm{~mm}$, most of which occurs from June to September. The main crops in this area are cotton, wheat, and maize. The soil in the experiment site is heavy loam, and the previous crop is cotton. Some chemical properties for the topsoil sampled at $0-15 \mathrm{~cm}$ depth were as follows: soil organic matter, $13.1 \mathrm{~g} \cdot \mathrm{kg}^{-1}$; total soil nitrogen, $0.9 \mathrm{~g} \cdot \mathrm{kg}^{-1}$; available soil phosphorus, $66.3 \mathrm{mg} \cdot \mathrm{kg}^{-1}$; available soil potassium, $169.8 \mathrm{mg} \cdot \mathrm{kg}^{-1}$.

2.2. Treatments and Field Work. The field experiment comprised two factors during the cotton growing seasons of 2011, including different irrigation methods (furrow irrigation and drip irrigation) and fertilization regimes (conventional fertilization and conventional fertilization + biochar). The four treatments included (1) FC, furrow irrigation (mulchfree) with conventional fertilization; (2) DC, drip irrigation (plastic film mulching) with conventional fertilization; (3) FB, furrow irrigation (mulch-free) with conventional fertilization + biochar; (4) DB, drip irrigation (plastic film mulching) with conventional fertilization + biochar. The experiment was a randomized block design with three replicates. The size of each experimental plot was $40 \mathrm{~m}^{2}(5 \mathrm{~m} \times 8 \mathrm{~m})$. As shown in Figure 1, the cotton was planted in narrow row spacing of $30 \mathrm{~cm}$ and wide row spacing of $60 \mathrm{~cm}$, with plant spacing of $10 \mathrm{~cm}$. For treatments of DC and DB, transplant plastic film in width of $120 \mathrm{~cm}$ covered four rows.

Seeds (Xinjiang cotton cv. number 36) were sown on April 27 and emerged on May 5. The fertilization and irritation were applied according to the local farming regime. The irrigation volumes were $4500 \mathrm{~m}^{3} \mathrm{ha}^{-1}$ and $6000 \mathrm{~m}^{3} \mathrm{ha}^{-1}$ for drip irrigation treatments (DC and DB) and furrow irrigation treatments (FC and FB), respectively. The biochar (Sanli New Energy, China) was applied as basal fertilizer at a rate of $7500 \mathrm{~kg} \mathrm{hm}^{-2}$. Chemical fertilizer was applied at the same total rate of diammonium phosphate $\left(300 \mathrm{~kg} \cdot \mathrm{hm}^{-2}\right)$, urea $\left(555 \mathrm{~kg} \cdot \mathrm{hm}^{-2}\right)$, and potassium dihydrogen phosphate $\left(90 \mathrm{~kg} \cdot \mathrm{hm}^{-2}\right)$ for all treatments. Diammonium phosphate was applied as basal fertilizer. The percentages for dressing fertilizer were different for two irrigation methods: the topdressing was applied in three times from June 10 to July 10 for furrow irrigation treatments, while the topdressing was fertigated with the drip irrigation system in several times for the drip irrigation treatments. The detail of fertilization and irrigation for these four treatments was shown in Table 1.

2.3. Investigation of $G H G$ Emissions. GHG fluxes from cotton field were measured using static chamber and gas chromatography method [23]. The size of chambers was $80 \mathrm{~cm}$ $\times 80 \mathrm{~cm} \times 45(90) \mathrm{cm}$ (length $\times$ width $\times$ height); the height of chambers was adapted to cotton plant growth. The gas sampling was carried out between 9:00 and 11:00 hours. Gas samples were drawn from the chambers through a three-way stopcock using an airtight syringe with volume of $50 \mathrm{~mL}$ at 0 , 10,20 , and $30 \mathrm{~min}$ after closure and immediately transferred into $50 \mathrm{~mL}$ vacuum glass container. The GHG fluxes from all plots were measured at 7-day interval. The gas samples were analyzed for the concentrations of $\mathrm{N}_{2} \mathrm{O}$ and $\mathrm{CH}_{4}$ using a gas chromatograph (Agilent 7890, Agilent Technologies, USA) equipped with an electron capture detector (ECD) and a flame ionization detector (FID). The rates of $\mathrm{N}_{2} \mathrm{O}$ and 
TABLE 1: The applications of irrigation and topdressing during the cotton growth period.

\begin{tabular}{|c|c|c|c|c|c|c|}
\hline \multirow{2}{*}{ Irrigation date } & \multicolumn{3}{|c|}{ Drip irrigation treatments } & \multicolumn{3}{|c|}{ Furrow irrigation treatments } \\
\hline & $\begin{array}{c}\text { Volume } \\
\left(\mathrm{m}^{3} \cdot \mathrm{hm}^{-2}\right)\end{array}$ & Urea $\left(\mathrm{kg} \cdot \mathrm{hm}^{-2}\right)$ & $\begin{array}{l}\text { Potassium dihydrogen } \\
\text { phosphate }\left(\mathrm{kg} \cdot \mathrm{hm}^{-2}\right)\end{array}$ & $\begin{array}{c}\text { Volume } \\
\left(\mathrm{m}^{3} \cdot \mathrm{hm}^{-2}\right)\end{array}$ & Urea $\left(\mathrm{kg} \cdot \mathrm{hm}^{-2}\right)$ & $\begin{array}{c}\text { Potassium dihydrogen } \\
\text { phosphate }\left(\mathrm{kg} \cdot \mathrm{hm}^{-2}\right)\end{array}$ \\
\hline $6.10-6.11$ & 225 & 30 & 15 & 1050 & 150 & \\
\hline $6.24-6.25$ & 300 & 30 & 15 & 1500 & 300 & 60 \\
\hline 7.3 & 300 & 30 & & & & \\
\hline 7.9-7.10 & 375 & 60 & & 1500 & 105 & 30 \\
\hline 7.17 & 450 & 75 & & & & \\
\hline $7.23-7.24$ & 450 & 75 & & 1200 & & \\
\hline 8.1 & 450 & 60 & & & & \\
\hline $8.5-8.6$ & 450 & 60 & & 750 & & \\
\hline 8.13 & 375 & 45 & 15 & & & \\
\hline 8.21 & 375 & 45 & 15 & & & \\
\hline 8.27 & 300 & 30 & 15 & & & \\
\hline 9.3 & 225 & 15 & 15 & & & \\
\hline 9.10 & 225 & & & & & \\
\hline
\end{tabular}

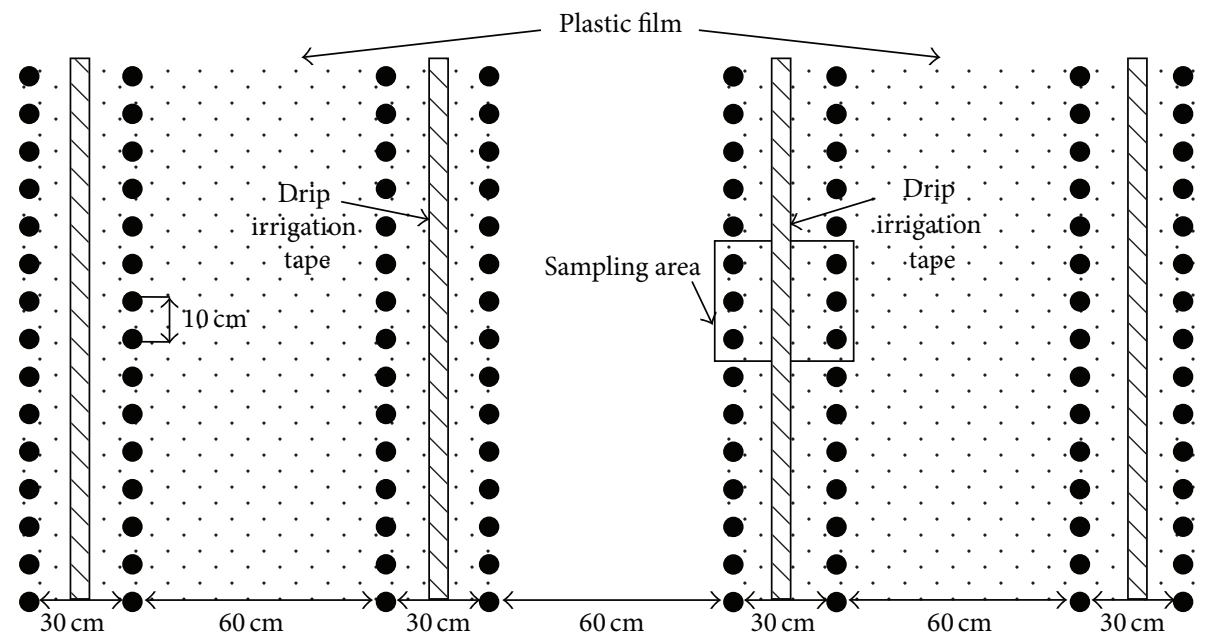

(a)

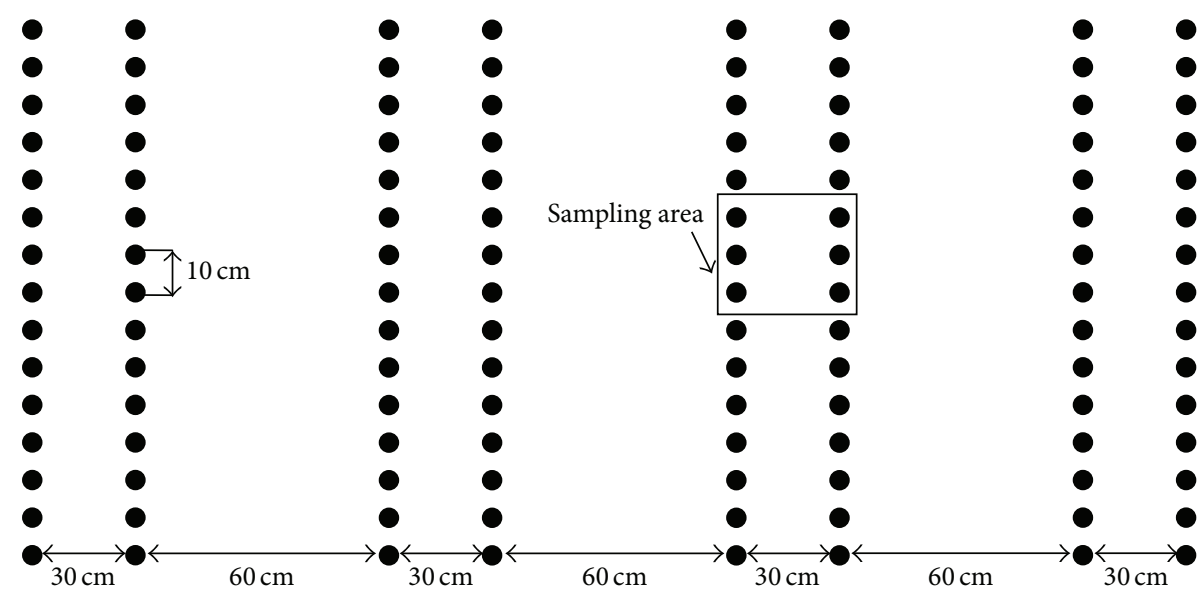

(b)

FIGURE 1: Experimental layout in the cotton field for drip irrigation treatments (DC, DB) (a) and furrow irrigation treatments (FC, FB) (b). 
$\mathrm{CH}_{4}$ flux were calculated by the linear increase of the gas concentration at each sampling time $(0,10,20$, and $30 \mathrm{~min})$; sample sets were rejected unless the correlation coefficient $\left(R^{2}\right)$ for the linear regression is greater than $0.9(0.7$ for small flux rates). All flux rates were adjusted for air temperature, air pressure, and area and volume of the chamber [24]. Average GHG fluxes were calculated by triplicate plots. Seasonal accumulation amounts of GHG emissions were calculated by the emissions between every two adjacent intervals of the measurements.

2.4. Soil Temperature, Moisture, and Mineral N Content. Soil temperature and soil moisture were measured at four different points near the area covered by the chamber. Soil temperature was taken at $5 \mathrm{~cm}$ depth. Soil moisture was determined using a TDR (time domain reflectometer) [25].

Surface soil samples $(0-20 \mathrm{~cm})$ at the experiment plots close to the chamber covered area were collected for the analysis of soil mineral $\mathrm{N}$ (ammonium and nitrate) contents at the same day as the gas sampling during the cotton growth season. Fresh soil samples were extracted with $0.01 \mathrm{M} \mathrm{CaCl}_{2}$ in a 1:10 ratio of soil to extractant. The concentrations of ammonium and nitrate in the extract were analyzed using continuous flow analytical system [26]. Cotton yield was recorded at cotton harvest.

2.5. Statistical Analyses. Differences in seasonal $\mathrm{N}_{2} \mathrm{O}$ and $\mathrm{CH}_{4}$ emissions, soil temperature, soil $\mathrm{N}$ mineral contents, and cotton yield as affected by irrigation methods and fertilization regimes were examined by using a two-way analysis of variance (ANOVA). The statistical analysis was carried out using SPSS 20.0 (IBM SPSS Statistics, Chicago, IL, USA).

\section{Results}

3.1. Soil Characteristics, Cotton Yield, and Water Use Efficiency. The soil moisture under FC and FB was significantly higher than that under DC and DB on June 30, July 14, and July 28, while on other days the soil moisture with FC and FB was close to that with DC and DB (Figure 2(a)). The soil temperatures during cotton growing season were significantly higher with $\mathrm{DC}$ and $\mathrm{DB}$ than with $\mathrm{FC}$ and $\mathrm{FB}$ during the bud stage $(P<0.05)$ (Table 2$)$. As compared with FC, DC showed significantly lower soil temperature during flowering and boll-forming stage $(P<0.05)$ (Table 2$)$. However, fertilization regimes had no effect on soil temperature. The soil $\mathrm{NO}_{3}{ }^{-}-\mathrm{N}$ contents were significantly higher with $\mathrm{FC}$ and FB than with DC and DB during the bud stage, and that with FB was significantly higher than those with FC, DC, and DB during the flowering and boll-forming stage $(P<0.05)$ (Table 2, Figure 3(b)), which was caused by the topdressing of $\mathrm{N}$ fertilizer in furrow irrigation plots. This topdressing event also led to a peak in soil $\mathrm{NH}_{4}{ }^{+}-\mathrm{N}$ contents with $\mathrm{FC}$ and $\mathrm{FB}$ on June 23 and June 30 (Figure 3(c)).

Although there was no significant difference between the cotton yield among these four treatments, the water use efficiency (WUE) calculated on cotton yield per unit irrigation volume was significantly higher with DC and DB than that with FC by $53.8 \%$ and $60.2 \%$, respectively $(P<0.05)$ (Table 3).

3.2. $\mathrm{N}_{2} \mathrm{O}$ Fluxes. The $\mathrm{N}_{2} \mathrm{O}$ flux rates with $\mathrm{FC}$ varied from $7.0 \mu \mathrm{g} \mathrm{m}^{-2} \mathrm{~h}^{-1}$ to $320.9 \mu \mathrm{g} \mathrm{m}^{-2} \mathrm{~h}^{-1}$ during the cotton growing season, with two flux peaks on June 30 and July 21 (Figure 4(a)). As compared with $\mathrm{FC}$, the $\mathrm{N}_{2} \mathrm{O}$ flux rates of FB were relatively stable and lower. Under DC, the $\mathrm{N}_{2} \mathrm{O}$ flux rates were relatively lower among the sampling dates comparing to FC, except a flux peak on August 9. On most days, the $\mathrm{N}_{2} \mathrm{O}$ flux rates with $\mathrm{DB}$ were close to that with DC (Figure 4(a)). The accumulated $\mathrm{N}_{2} \mathrm{O}$ emissions during the cotton growing season were significantly lower with $\mathrm{FB}$, DC, and DB than that with FC by $28.8 \%, 36.1 \%$, and $37.6 \%$, respectively $(P<0.05)$ (Table 4$)$. At different growth stages, the highest $\mathrm{N}_{2} \mathrm{O}$ flux rate under FC, DC, and DB appeared at the flowering and boll-forming stage, while $\mathrm{FB}$ appeared at the bud stage (Figure $4(\mathrm{~b})$ ). The $\mathrm{N}_{2} \mathrm{O}$ flux rate with $\mathrm{FC}$ performed differently with other three treatments at the flowering and boll-forming stage and the bud stage $(P<$ 0.05). No significant difference was observed between DC and DB during the whole period.

3.3. $\mathrm{CH}_{4}$ Fluxes. The $\mathrm{CH}_{4}$ flux rates under $\mathrm{FC}, \mathrm{DC}$, and $\mathrm{DB}$ were below zero on most sampling days, indicating that cotton fields were the sink of $\mathrm{CH}_{4}$ except under $\mathrm{FB}$ for most of the time of the cotton growing season (Figure 5(a)). The $\mathrm{CH}_{4}$ flux rates were similar under the four treatments in May and June but diverged after June. The highest uptake of $\mathrm{CH}_{4}$ appeared at the flowering and boll-forming stage under FC and DB, while it appeared at the bud stage under DC (Figure 5(b)). The accumulated $\mathrm{CH}_{4}$ emissions during the cotton growing season were significantly lower with DC and DB than that with FB by $264.5 \%$ and $226.7 \%$, respectively $(P<0.05)$ (Table 4). Although the accumulated $\mathrm{CH}_{4}$ emission under $\mathrm{FC}$ was $154.2 \%$ lower than that with $\mathrm{FB}$, there was little difference between the two treatments.

3.4. Yield-Scaled GWP. The total GWP of $\mathrm{N}_{2} \mathrm{O}$ and $\mathrm{CH}_{4}$ emissions during cotton growing season was 102.89, 146.23, 435.09, and 496.49 under treatments of DC, DB, FC, and FB, respectively (Figure 6(a)). Cotton fields under DC, DB, and FC were all sinks for $\mathrm{CH}_{4}$, which reduced the contribution of $\mathrm{N}_{2} \mathrm{O}$ emission to the overall GWP by $68.3 \%, 53.9 \%$, and $14.4 \%$, respectively. The yield-scaled GWP calculated by GWP per unit cotton yield with FC and FB were significantly higher than those with DC and DB $(P<0.01)$ (Figure 6(b)). As compared with FC, DC and DB were $80.1 \%$ and $72.2 \%$ lower in yield-scaled GWP, respectively. Irrigation methods showed extremely significant effect on the total GWP and yield-scaled GWP $(P<0.01)$, while fertilization regimes had no effect on both.

\section{Discussion}

In the present study, it was observed that the soil temperature during cotton growing season was higher with DC and DB than with $\mathrm{FC}$ and $\mathrm{FB}$ in most of the time during cotton 


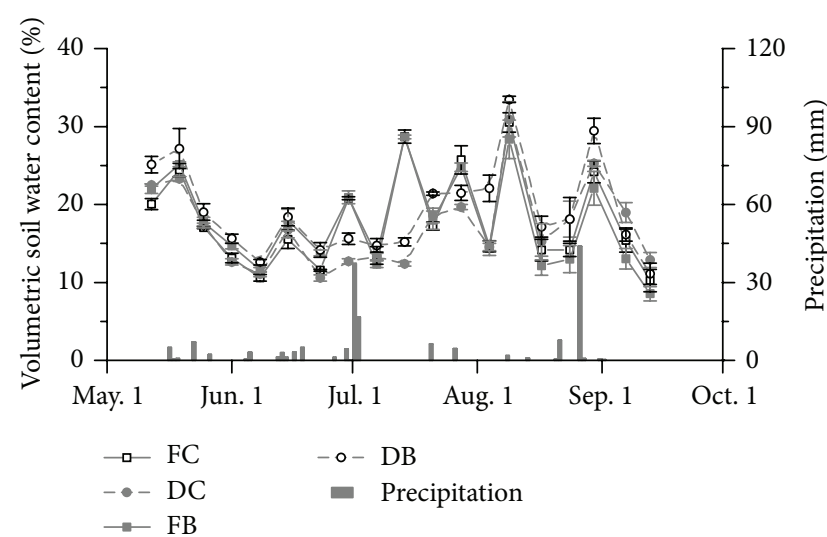

(a)

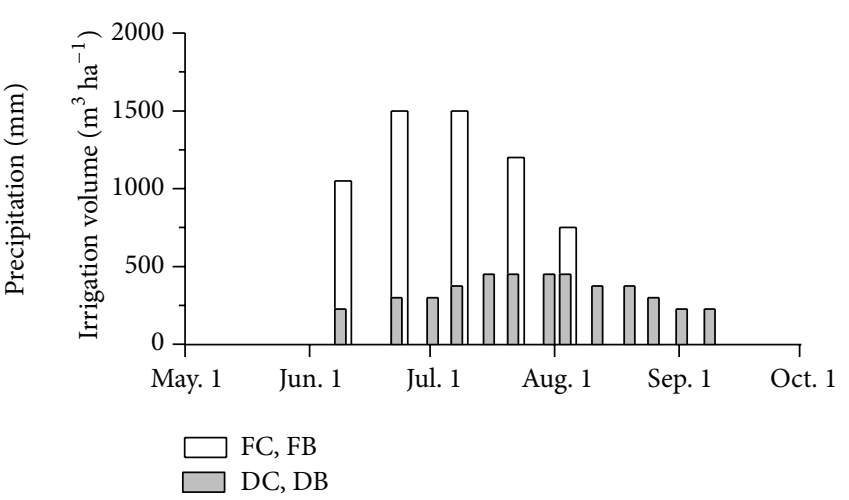

(b)

FIGURE 2: Effects of different irrigation methods and fertilization regimes on soil moisture, precipitation, and volume of irrigation water during cotton growing season.

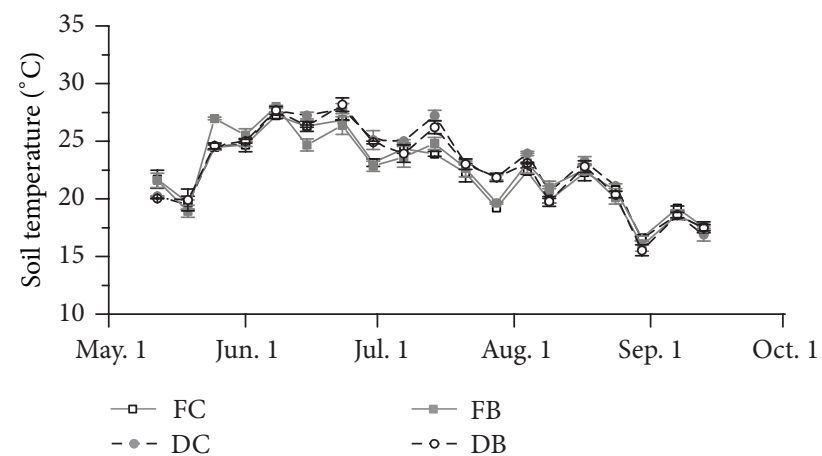

(a)

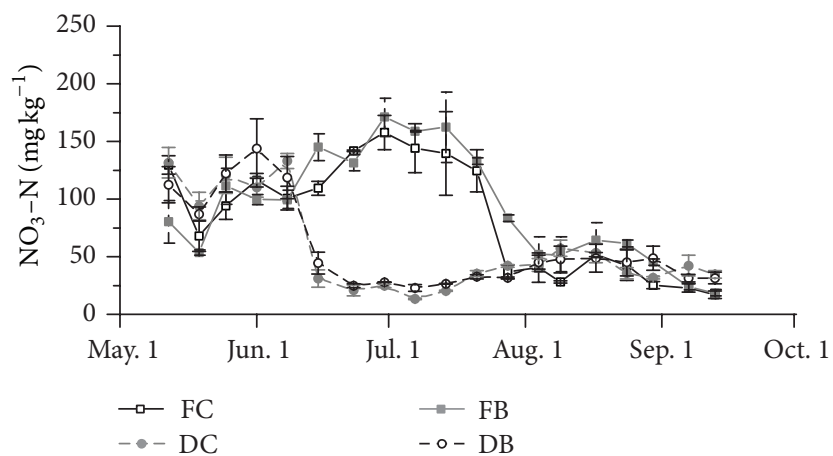

(b)

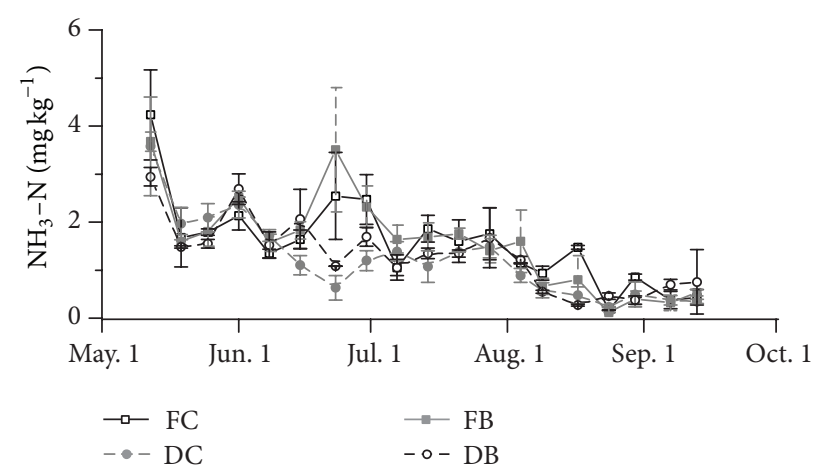

(c)

FIGURE 3: Effects of different irrigation methods and fertilization regimes on soil temperature and mineral $\mathrm{N}$ contents during cotton growing season.

growing season for the plastic film mulching. A similar result was found in the previous study for different irrigation methods in maize field in China [27]. The plastic film usually prevents the evaporation of soil moisture [22]. However, the difference of the soil moisture between four treatments was primarily attributed to the water supply regimes (Figure 2). The plastic film showed little effect on maintenance of soil moisture in the present study. Biochar can efficiently retain soil moisture due to its special physical structure [18], which was consistent with our results under DC and DB.

The emissions of $\mathrm{N}_{2} \mathrm{O}$ and $\mathrm{CH}_{4}$ from cotton field were investigated under different irrigation methods and fertilization regimes in an arid area of northwestern China. The accumulated $\mathrm{N}_{2} \mathrm{O}$ emissions during cotton growth season in this study were lower than that from semiarid cotton field in northern China [4] and arid cotton fields in Uzbekistan 


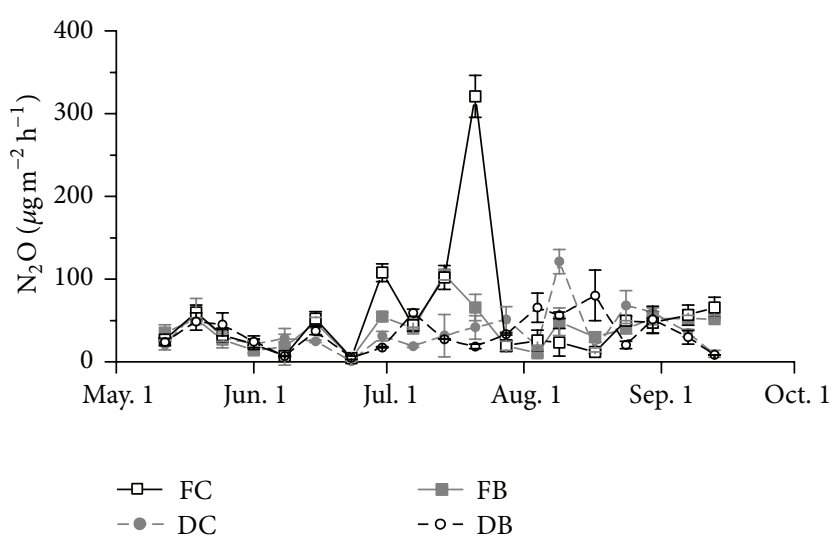

(a)

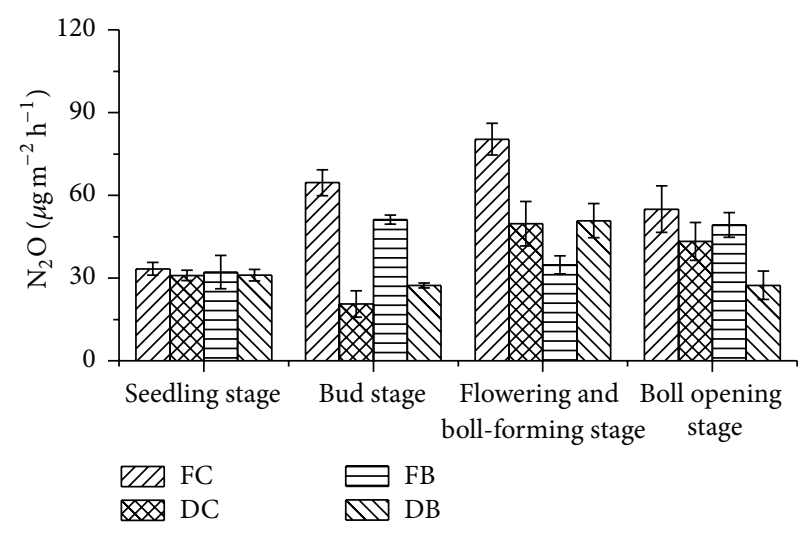

(b)

FIGURE 4: Effects of different irrigation methods and fertilization regimes on $\mathrm{N}_{2} \mathrm{O}$ flux rates during cotton growing season.

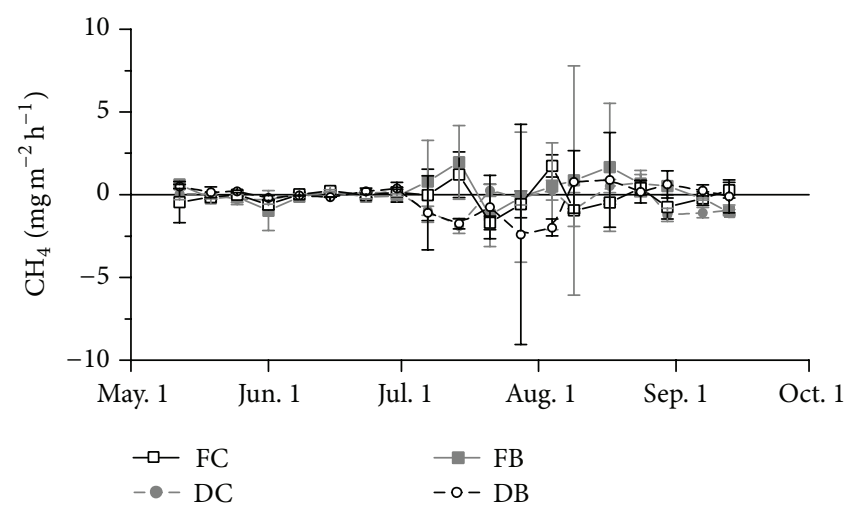

(a)

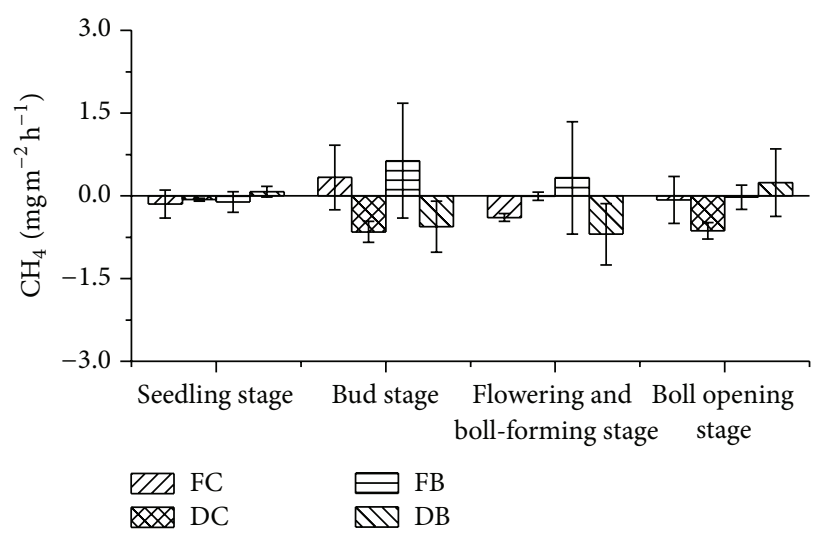

(b)

Figure 5: Effects of different irrigation methods and fertilization regimes on $\mathrm{CH}_{4}$ flux rates during cotton growing season.

[6] but higher than the $\mathrm{N}_{2} \mathrm{O}$ emissions from semiarid cotton field in Pakistan [5]. The variance in $\mathrm{N}_{2} \mathrm{O}$ emission among different ecosites might be attributed to the difference in $\mathrm{N}$ fertilizer application rate, irrigation, climate factors, and soil properties [28-33]. Here, lower level of $\mathrm{N}_{2} \mathrm{O}$ emission from cotton field was found under FB, DC, and DB, in relation to $\mathrm{FC}$ with a high $\mathrm{N}$ fertilizer application rate $\left(300 \mathrm{~kg} \mathrm{~N} \mathrm{ha}^{-1}\right)$ (Table 4). The relatively lower $\mathrm{N}_{2} \mathrm{O}$ emission from cotton field under drip irrigation treatments was mainly attributed to the water supply regime and $\mathrm{N}$ fertilizer dressing method (socalled fertigation) in drip irrigation system, which favored decrease in $\mathrm{N}_{2} \mathrm{O}$ emission. In detail, the soil moisture was lower in cotton field with drip irrigation treatments than that with FC during the bud stage, which was the main fertilization time of FC. Previous studies reported that soil moisture is a key factor in regulation of $\mathrm{N}_{2} \mathrm{O}$ emission from agricultural soil. For instance, the $\mathrm{N}_{2} \mathrm{O}$ emission was enhanced along with increased soil moisture in a given range, due to the improved denitrification [34-36]. Therefore, the relatively lower soil moisture in cotton field with DC and DB during the bud stage could reduce the $\mathrm{N}_{2} \mathrm{O}$ emission more effectively than that with FC. Furthermore, the decreased $\mathrm{N}$ fertilizer was directly fertigated to the rhizosphere of cotton plants in drip irrigation treatments with more times but less application rate per time. This $\mathrm{N}$ fertilizer dressing method could also improve $\mathrm{N}$ uptake of cotton plant but decrease the soil inorganic $\mathrm{N}$ pool $\left(\mathrm{NO}_{3}{ }^{-}-\mathrm{N}\right.$ and $\mathrm{NH}_{4}{ }^{+}-\mathrm{N}$ ) (Table 2 ) and hence reduce $\mathrm{N}$ source for $\mathrm{N}_{2} \mathrm{O}$ emission, which was significantly correlated with soil $\mathrm{N}$ [37]. However, the observed reduction in $\mathrm{N}_{2} \mathrm{O}$ emission caused by drip irrigation was less than that in previous studies conducted in the melon and tomato fields [8-10]. This might be related to higher $\mathrm{N}$ fertilizer application rate in this study $\left(300 \mathrm{~kg} \mathrm{~N} \mathrm{ha}^{-1}\right)$, suggesting that the mitigation effect of drip irrigation on $\mathrm{N}_{2} \mathrm{O}$ may be depressed with a higher $\mathrm{N}$ fertilizer application rate.

Although FB and FC used the same irrigation system, FB showed lower $\mathrm{N}_{2} \mathrm{O}$ emission than $\mathrm{FC}$ for the addition of biochar. A similar result was found in wheat field [14, 15]. However, the effect of biochar on $\mathrm{N}_{2} \mathrm{O}$ emissions under $\mathrm{DB}$ and DC was covered up by the effect of drip irrigation. Biochar had been shown to efficiently retain $\mathrm{NH}_{4}{ }^{+}$via cation exchange by its developed specific surface area and surface negative charge density [38]. Then the retained $\mathrm{N}$ would be slowly released for plant growth; thus, biochar could 


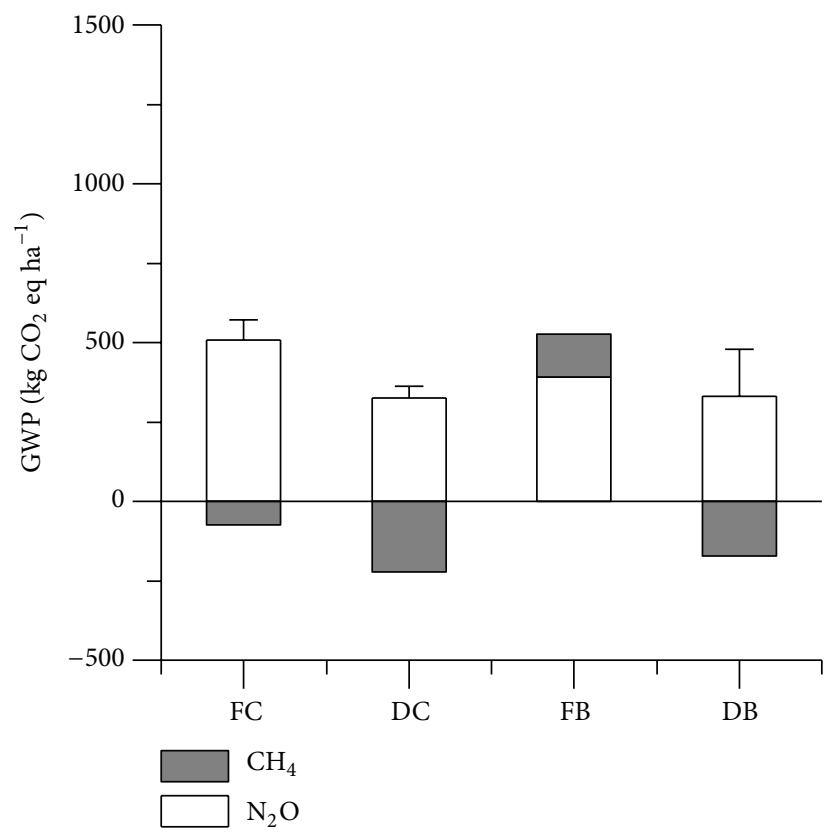

(a) Overall GWP

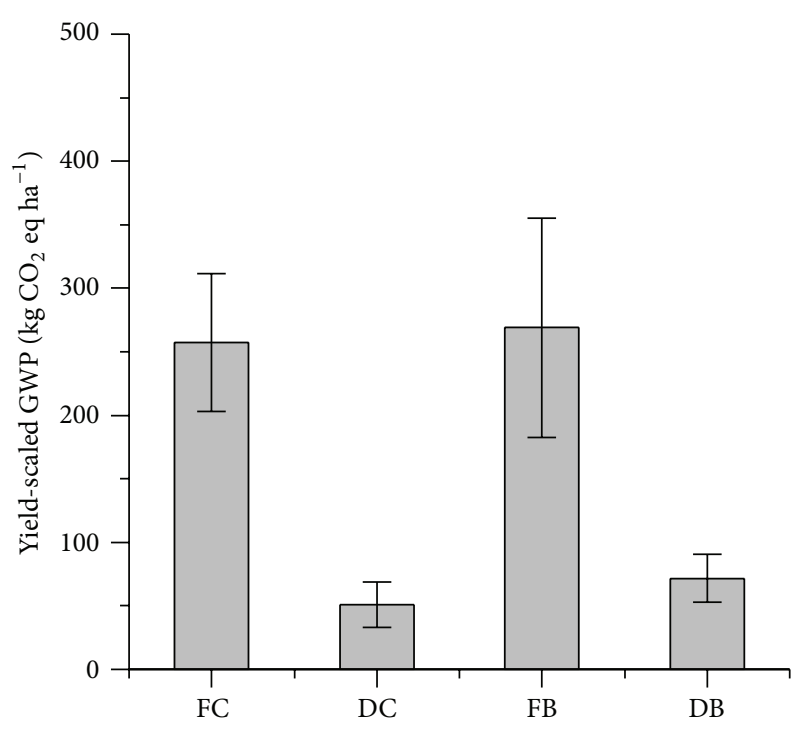

(b) Yield-scaled GWP

FIGURE 6: Overall GWP of GHGs (a) and yield-scaled GWP (b) for different treatments. The error bar in (a) was the standard error of overall GWP of $\mathrm{N}_{2} \mathrm{O}$ and $\mathrm{CH}_{4}$ emissions.

TABLE 2: Effects of different irrigation methods and fertilization regimes on major soil characteristics. Values are means \pm standard deviation of three replicates. Different small letters in the same column refer to significant difference between treatments at $P<0.05$ level.

\begin{tabular}{|c|c|c|c|c|}
\hline & Seedling stage & Bud stage & Flowering and boll-forming stage & Boll opening stage \\
\hline \multicolumn{5}{|c|}{ Soil moisture (\%) } \\
\hline FC & $16.79 \pm 0.37 b$ & $18.63 \pm 0.25 a$ & $20.46 \pm 1.04 \mathrm{a}$ & $16.00 \pm 1.25 b$ \\
\hline DC & $17.28 \pm 0.05 b$ & $12.24 \pm 0.13 c$ & $19.79 \pm 1.00 \mathrm{a}$ & $18.81 \pm 1.13 a$ \\
\hline FB & $18.19 \pm 0.35 \mathrm{ab}$ & $18.92 \pm 0.35 \mathrm{a}$ & $19.52 \pm 0.85 a$ & $14.16 \pm 1.50 \mathrm{~b}$ \\
\hline DB & $19.65 \pm 0.71 \mathrm{a}$ & $14.93 \pm 0.69 b$ & $23.11 \pm 0.82 \mathrm{a}$ & $18.70 \pm 1.56 \mathrm{a}$ \\
\hline \multicolumn{5}{|c|}{ Soil temperature $\left({ }^{\circ} \mathrm{C}\right)$} \\
\hline FC & $24.01 \pm 0.33 a$ & $24.55 \pm 0.12 b$ & $21.2 \pm 0.12 b$ & $18.53 \pm 0.10 \mathrm{a}$ \\
\hline DC & $23.98 \pm 0.12 \mathrm{a}$ & $26.29 \pm 0.25 a$ & $22.55 \pm 0.15 a$ & $18.29 \pm 0.27 a$ \\
\hline FB & $24.28 \pm 0.19 \mathrm{a}$ & $24.41 \pm 0.36 b$ & $21.78 \pm 0.37 \mathrm{ab}$ & $18.03 \pm 0.37 \mathrm{a}$ \\
\hline DB & $23.92 \pm 0.09 \mathrm{a}$ & $25.80 \pm 0.37 \mathrm{a}$ & $22.11 \pm 0.33 \mathrm{ab}$ & $18.00 \pm 0.05 a$ \\
\hline \multicolumn{5}{|c|}{ Soil $\mathrm{NO}_{3}{ }^{-}-\mathrm{N}\left(\mathrm{mg} \mathrm{kg}^{-1}\right)$} \\
\hline FC & $100.82 \pm 4.03 \mathrm{a}$ & $145.82 \pm 3.52 \mathrm{a}$ & $56.38 \pm 6.68 b$ & $26.94 \pm 4.18 \mathrm{a}$ \\
\hline $\mathrm{DC}$ & $108.44 \pm 3.39 \mathrm{a}$ & $19.80 \pm 1.44 \mathrm{~b}$ & $46.11 \pm 1.29 b$ & $38.77 \pm 5.15 \mathrm{a}$ \\
\hline FB & $98.24 \pm 6.86 a$ & $155.94 \pm 12.38 \mathrm{a}$ & $76.94 \pm 2.49 a$ & $37.26 \pm 0.12 \mathrm{a}$ \\
\hline DB & $104.75 \pm 5.31 \mathrm{a}$ & $25.54 \pm 0.80 \mathrm{~b}$ & $41.13 \pm 4.90 \mathrm{~b}$ & $39.19 \pm 6.45 a$ \\
\hline \multicolumn{5}{|c|}{ Soil $\mathrm{NO}_{4}^{+}-\mathrm{N}\left(\mathrm{mg} \mathrm{kg}^{-1}\right)$} \\
\hline $\mathrm{FC}$ & $2.14 \pm 0.28 \mathrm{a}$ & $1.98 \pm 0.41 \mathrm{ab}$ & $1.38 \pm 0.19 \mathrm{a}$ & $0.46 \pm 0.08 \mathrm{a}$ \\
\hline $\mathrm{DC}$ & $2.14 \pm 0.21 \mathrm{a}$ & $1.07 \pm 0.13 b$ & $0.96 \pm 0.01 \mathrm{a}$ & $0.36 \pm 0.08 \mathrm{a}$ \\
\hline FB & $2.17 \pm 0.05 \mathrm{a}$ & $2.29 \pm 0.16 \mathrm{a}$ & $1.24 \pm 0.24 \mathrm{a}$ & $0.34 \pm 0.05 a$ \\
\hline DB & $2.04 \pm 0.11 \mathrm{a}$ & $1.29 \pm 0.06 \mathrm{~b}$ & $1.01 \pm 0.12 \mathrm{a}$ & $0.57 \pm 0.16 \mathrm{a}$ \\
\hline
\end{tabular}

TABLE 3: Effects of different irrigation methods and fertilization regimes on cotton yield and water use efficiency. Values are means \pm standard deviation of three replicates. Different small letters in the same column refer to significant difference between treatments at $P<0.05$ level.

\begin{tabular}{lcccc}
\hline & FC & DC & FB & DB \\
\hline Cotton yield $\left(\mathrm{Mg} \mathrm{ha}^{-1}\right)$ & $1.76 \pm 0.16 \mathrm{a}$ & $2.02 \pm 0.10 \mathrm{a}$ & $1.94 \pm 0.17 \mathrm{a}$ & $2.11 \pm 0.14 \mathrm{a}$ \\
Water use efficiency $\left(\mathrm{kg} \mathrm{m}^{-3}\right)$ & $0.29 \pm 0.03 \mathrm{~b}$ & $0.45 \pm 0.02 \mathrm{a}$ & $0.32 \pm 0.03 \mathrm{~b}$ & $0.47 \pm 0.03 \mathrm{a}$ \\
\hline
\end{tabular}


TABLE 4: Effects of different irrigation methods and fertilization regimes on accumulated $\mathrm{N}_{2} \mathrm{O}$ and $\mathrm{CH}_{4}$ emissions during cotton growing season. Values are means \pm standard deviation of three replicates. Different small letters in the same column refer to significant difference between treatments at $P<0.05$ level.

\begin{tabular}{lcc}
\hline & $\mathrm{N}_{2} \mathrm{O}\left(\mathrm{kg} \mathrm{ha}^{-1}\right)$ & $\mathrm{CH}_{4}\left(\mathrm{~kg} \mathrm{ha}^{-1}\right)$ \\
\hline FC & $1.71 \pm 0.13 \mathrm{a}$ & $-2.92 \pm 0.96 \mathrm{ab}$ \\
$\mathrm{DC}$ & $1.09 \pm 0.11 \mathrm{~b}$ & $-8.87 \pm 1.85 \mathrm{~b}$ \\
$\mathrm{FB}$ & $1.21 \pm 0.07 \mathrm{~b}$ & $5.39 \pm 4.91 \mathrm{a}$ \\
$\mathrm{DB}$ & $1.04 \pm 0.06 \mathrm{~b}$ & $-6.84 \pm 1.07 \mathrm{~b}$ \\
\hline
\end{tabular}

coordinate the mineral $\mathrm{N}$ availability and plant uptake. This would reduce the amount of $\mathrm{N}$ available for denitrification and lost as $\mathrm{N}_{2} \mathrm{O}$ [18]. On the other hand, decreases in emissions of $\mathrm{N}_{2} \mathrm{O}$ in soil amended with biochar might be attributed to improved aeration and porosity for its developed microstructure, which might lead to lower denitrification rates and alter the $\mathrm{N}_{2} \mathrm{O}$-to- $\mathrm{N}_{2}$ ratio during denitrification [16].

The present study indicated that the arid cotton fields under $\mathrm{FC}, \mathrm{DC}$, and $\mathrm{DB}$ were the sinks of $\mathrm{CH}_{4}$, while $\mathrm{FB}$ was the source of $\mathrm{CH}_{4}$. This was consistent with the results of previous studies with different irrigation methods conducted in upland field [39-41]. However, drip irrigation was a source of $\mathrm{CH}_{4}$ in the study in cotton field [22], which was inconsistent with the present results. This might be related to the different rate of irrigation and fertilization. Upland fields are normally net sinks for $\mathrm{CH}_{4}$, since the consumption exceeds the production in $\mathrm{CH}_{4}$ [42]. The dry soil in upland field limited the $\mathrm{CH}_{4}$ emission; however, it did have a possibility to become a source after rainfall within several days or weeks $[43,44]$. Comparing the $\mathrm{CH}_{4}$ emission between DC and FC, it was shown that DC increased the uptake of $\mathrm{CH}_{4}$ for the relative lower soil moisture in most of the time during cotton growing season (Figure 2(a)). The main factor affecting $\mathrm{CH}_{4}$ uptake in summer was soil moisture [45], which plays a critical role in $\mathrm{CH}_{4}$ consumption [46]. Decrease in soil moisture enhanced $\mathrm{CH}_{4}$ oxidation through improving $\mathrm{CH}_{4}$ diffusion from atmosphere into soil pore spaces [47] and through gas diffusivity to control microbial oxidation, which changes inversely with soil moisture $[48,49]$.

In our study, the addition of biochar increased $\mathrm{CH}_{4}$ emissions by $284.6 \%$ higher with $\mathrm{FB}$ than that with $\mathrm{FC}$, while the uptake of $\mathrm{CH}_{4}$ with DB was $22.9 \%$ lower than that with DC. The result was in good agreement with previous study that biochar addition promoted $\mathrm{CH}_{4}$ emissions of the upland soil [17]. However, other studies had reported that biochar amendment reduces $\mathrm{CH}_{4}$ emissions as compared with the control $[18,19]$. The inconsistence might be attributed to the soil type, agricultural management, and biochar type. On one hand, the addition of biochar increased the substrate supply and created a favorable environment for methanogenic activity. On the other hand, the $\mathrm{CH}_{4}$ emission from acid soil was usually much lower than that from neutral soil [50]. Biochar addition could increase soil PH, which was a benefit for methanogenic bacteria. Furthermore, increased soil aeration due to increased porosity could increase $\mathrm{CH}_{4}$ diffusion. Biochar might play a more important role under paddy fields, compared with straw returning directly, which would increase $\mathrm{CH}_{4}$ emission obviously [51].

There was significant difference between drip irrigation treatments and furrow irrigation treatments in the total GWP of $\mathrm{N}_{2} \mathrm{O}$ and $\mathrm{CH}_{4}$ emissions $(P<0.01)$, while fertilization regimes showed little effect (Figure 6 ). The average yieldscaled GWP was $80.1 \%$ and $72.2 \%$ lower with DC and DB than that with FC, indicating that drip irrigation could mitigate the yield-scaled GHG emissions from cotton field. In previous studies, cotton yield was higher with drip irrigation than that with furrow irrigation [52], which agreed with our study. Although the difference of cotton yield between four treatments was insignificant, WUE was significantly higher with DC and DB than that with FC by $53.8 \%$ and $60.2 \%$, respectively $(P<0.05)$ (Table 3 ). WUE represented in this study (from $0.263 \mathrm{~kg} \mathrm{~m}^{-3}$ to $0.527 \mathrm{~kg} \mathrm{~m}^{-3}$ ) were lower than that from the studies in Turkey, where it ranged from $0.508 \mathrm{~kg} \mathrm{~m}^{-3}$ to $0.648 \mathrm{~kg} \mathrm{~m}^{-3}$ or from $0.76 \mathrm{~kg} \mathrm{~m}^{-3}$ to $1.46 \mathrm{~kg} \mathrm{~m}^{-3}[52,53]$. The variance in WUE in different ecosites could be related to climate, plant number, varietal differences, and irrigation amount [54]. It indicated that drip irrigation significantly increased WUE of cotton plants, in relation to furrow irrigation. The relative higher WUE with DC and DB was related to improved fertilizer efficiency and depressed leaching potential in drip irrigation system [55].

\section{Conclusions}

Irrigation methods significantly affected the GHG emissions from cotton field in arid northwestern China. Biochar addition increased $\mathrm{CH}_{4}$ emissions and decreased $\mathrm{N}_{2} \mathrm{O}$ emissions. The water supply and $\mathrm{N}$ fertilizer dressing method played a key role in regulating gas emissions. Drip irrigation treatments (DC and DB) remarkably reduced GHG emissions, compared with furrow irrigation treatments (FC and $\mathrm{FB}$ ). In addition, drip irrigation treatments (DC and DB) had higher yield and WUE, compared to furrow irrigation treatments (FC and FB). Thus, mulched-drip irrigation with conventional fertilization or conventional fertilization + biochar should be a better approach to increase cotton yield with depressed GHG emissions in arid northwestern China.

\section{Abbreviations}

GHG: Greenhouse gas

GWP: Global warming potential

WUE: Water use efficiency.

\section{Conflict of Interests}

The authors declare that there is no conflict of interests regarding the publication of this paper.

\section{Acknowledgment}

This work was financially supported by the opened subject of Xinjiang Key Laboratory of Water Cycle and Utilization in Arid Zone (Grant no. XJYS0907-2010-03). 


\section{References}

[1] IPCC, Climate Change 2007: The Physical Science Basis, Cambridge University Press, Cambridge, UK, 2007.

[2] A. F. Bouwman, L. J. M. Boumans, and N. H. Baffes, Global Estimates of Gaseous Emissions of $\mathrm{NH}_{3}, \mathrm{NO}$ and $\mathrm{N}_{2} \mathrm{O}$ from Agricultural Land, Food and Agriculture Organisation, Rome, Italy, 2001.

[3] FAOSTAT, 2002, http://faostat.fao.org/.

[4] C. Liu, X. Zheng, Z. Zhou et al., "Nitrous oxide and nitric oxide emissions from an irrigated cotton field in Northern China," Plant and Soil, vol. 332, no. 1-2, pp. 123-134, 2010.

[5] T. Mahmood, R. Ali, J. Iqbal, and U. Robab, "Nitrous oxide emission from an irrigated cotton field under semiarid subtropical conditions," Biology and Fertility of Soils, vol. 44, no. 5, pp. 773781, 2008.

[6] C. Scheer, R. Wassmann, K. Kienzler, N. Ibragimov, and R. Eschanov, "Nitrous oxide emissions from fertilized, irrigated cotton (Gossypium hirsutum L.) in the Aral Sea Basin, Uzbekistan: influence of nitrogen applications and irrigation practices," Soil Biology and Biochemistry, vol. 40, no. 2, pp. 290301, 2008 .

[7] J. Li, J. Zhang, and L. Ren, "Water and nitrogen distribution as affected by fertigation of ammonium nitrate from a point source," Irrigation Science, vol. 22, no. 1, pp. 19-30, 2003.

[8] C. M. Kallenbach, D. E. Rolston, and W. R. Horwath, "Cover cropping affects soil $\mathrm{N}_{2} \mathrm{O}$ and $\mathrm{CO}_{2}$ emissions differently depending on type of irrigation," Agriculture, Ecosystems and Environment, vol. 137, no. 3-4, pp. 251-260, 2010.

[9] L. Sánchez-Martín, A. Arce, A. Benito, L. Garcia-Torres, and A. Vallejo, "Influence of drip and furrow irrigation systems on nitrogen oxide emissions from a horticultural crop," Soil Biology and Biochemistry, vol. 40, no. 7, pp. 1698-1706, 2008.

[10] L. Sanchez-Martín, A. Meijide, L. Garcia-Torres, and A. Vallejo, "Combination of drip irrigation and organic fertilizer for mitigating emissions of nitrogen oxides in semiarid climate," Agriculture, Ecosystems and Environment, vol. 137, no. 1-2, pp. 99-107, 2010.

[11] J. Lehmann, "Bio-energy in the black," Frontiers in Ecology and the Environment, vol. 5, no. 7, pp. 381-387, 2007.

[12] M. Fowles, "Black carbon sequestration as an alternative to bioenergy," Biomass and Bioenergy, vol. 31, no. 6, pp. 426-432, 2007.

[13] M. Rondon, J. A. Ramirez, and J. Lehmann, "Charcoal additions reduce net emissions of greenhouse gases to the atmosphere," in Proceedings of the 3rd USDA Symposium on Greenhouse Gases and Carbon Sequestration, p. 208, Baltimore, Md, USA, March 2005.

[14] Á. Aguilar-Chávez, M. Díaz-Rojas, M. del Rosario CárdenasAquino, L. Dendooven, and M. Luna-Guido, "Greenhouse gas emissions from a wastewater sludge-amended soil cultivated with wheat (Triticum spp. L.) as affected by different application rates of charcoal," Soil Biology and Biochemistry, vol. 52, pp. 9095, 2012.

[15] S. Castaldi, M. Riondino, S. Baronti et al., "Impact of biochar application to a Mediterranean wheat crop on soil microbial activity and greenhouse gas fluxes," Chemosphere, vol. 85, no. 9, pp. 1464-1471, 2011.

[16] B. P. Singh, B. J. Hatton, B. Singh, A. L. Cowie, and A. Kathuria, "Influence of biochars on nitrous oxide emission and nitrogen leaching from two contrasting soils," Journal of Environmental Quality, vol. 39, no. 4, pp. 1224-1235, 2010.
[17] J. Wang, X. Pan, Y. Liu, X. Zhang, and Z. Xiong, "Effects of biochar amendment in two soils on greenhouse gas emissions and crop production," Plant and Soil, vol. 360, no. 1-2, pp. 287298, 2012.

[18] K. Karhu, T. Mattila, I. Bergström, and K. Regina, "Biochar addition to agricultural soil increased $\mathrm{CH}_{4}$ uptake and water holding capacity-results from a short-term pilot field study," Agriculture, Ecosystems and Environment, vol. 140, no. 1-2, pp. 309-313, 2011.

[19] C. Scheer, P. R. Grace, D. W. Rowlings, S. Kimber, and L. van Zwieten, "Effect of biochar amendment on the soil-atmosphere exchange of greenhouse gases from an intensive subtropical pasture in northern New South Wales, Australia," Plant and Soil, vol. 345, no. 1, pp. 47-58, 2011.

[20] Z. Li, R. Zhang, X. Wang, J. Wang, C. Zhang, and C. Tian, "Carbon dioxide fluxes and concentrations in a cotton field in northwestern China: effects of plastic mulching and drip irrigation," Pedosphere, vol. 21, no. 2, pp. 178-185, 2011.

[21] Q. Zhang, L. Yang, J. Wang, H. Luo, Y. Zhang, and W. Zhang, "Effects of different irrigation methods and fertilization measures on soil respiration and its component contribution in cotton field in arid region," Scientia Agricultura Sinica, vol. 25, no. 12, pp. 2420-2430, 2012 (Chinese).

[22] Z. Li, R. Zhang, X. Wang, F. Chen, D. Lai, and C. Tian, "Effects of plastic film mulching with drip irrigation on $\mathrm{N}_{2} \mathrm{O}$ and $\mathrm{CH}_{4}$ emissions from cotton fields in arid land," Journal of Agricultural Science, 2013.

[23] FAO/IAEA, Measurement of Methane and Nitrous Oxide Emission from Agriculture, A Joint Undertakong by the Food and Agriculture Organization of United Nations and International Atomic Energy Agency, International Atomic Energy Agency, Vienna, Austria, 1992.

[24] Y. Huang, J. Jiang, L. Zong, Q. Zhou, R. L. Sass, and F. M. Fisher, "Influence of planting density and precipitation on $\mathrm{N}_{2} \mathrm{O}$ emission from a winter wheat field," Environmental Science, vol. 22, no. 6, pp. 20-23, 2001 (Chinese).

[25] G. C. Topp, J. L. Davis, and A. P. Annan, "Electromagnetic determination of soil water content: measurements in coaxial transmission lines," Water Resources Research, vol. 16, no. 3, pp. 574-582, 1980.

[26] R. Lu, Soil Agricultural Chemistry Analytical Method, China Agricultural Science and Technology Press, Beijing, China, 2000.

[27] L. Zhou, F. Li, S. Jin, and Y. Song, "How two ridges and the furrow mulched with plastic film affect soil water, soil temperature and yield of maize on the semiarid Loess Plateau of China," Field Crops Research, vol. 113, no. 1, pp. 41-47, 2009.

[28] J. Clemens, M. P. Schillinger, H. Goldbach, and B. Huwe, "Spatial variability of $\mathrm{N}_{2} \mathrm{O}$ emissions and soil parameters of an arable silt loam-a field study," Biology and Fertility of Soils, vol. 28, no. 4, pp. 403-406, 1999.

[29] K. Inubushi, M. A. Barahona, and K. Yamakawa, "Effects of salts and moisture content on $\mathrm{N}_{2} \mathrm{O}$ emission and nitrogen dynamics in Yellow soil and Andosol in model experiments," Biology and Fertility of Soils, vol. 29, no. 4, pp. 401-407, 1999.

[30] B. J. Jørgensen and R. N. Jørgensen, “Field-scale and laboratory study of factors affecting $\mathrm{N}_{2} \mathrm{O}$ emissions from a rye stubble field on sandy loam soil," Biology and Fertility of Soils, vol. 25, no. 4, pp. 366-371, 1997.

[31] A. R. Mosier and Z. Zhu, "Changes in patterns of fertilizer nitrogen use in Asia and its consequences for $\mathrm{N}_{2} \mathrm{O}$ emissions 
from agricultural systems," Nutrient Cycling in Agroecosystems, vol. 57, no. 1, pp. 107-117, 2000.

[32] R. Ruser, H. Flessa, R. Schilling, F. Beese, and J. C. Munch, "Effect of crop-specific field management and $\mathrm{N}$ fertilization on $\mathrm{N}_{2} \mathrm{O}$ emissions from a fine-loamy soil," Nutrient Cycling in Agroecosystems, vol. 59, no. 2, pp. 177-191, 2001.

[33] C. Song and J. Zhang, "Effects of soil moisture, temperature, and nitrogen fertilization on soil respiration and nitrous oxide emission during maize growth period in northeast China," Acta Agriculturae Scandinavica B: Soil and Plant Science, vol. 59, no. 2, pp. 97-106, 2009.

[34] D. M. Linn and J. W. Doran, "Effect of water-filled pore space on carbon dioxide and nitrous oxide production in tilled and nontilled soils," Soil Science Society of America Journal, vol. 48, no. 6, pp. 1267-1272, 1984.

[35] X. J. Liu, A. R. Mosier, A. D. Halvorson, C. A. Reule, and F. S. Zhang, "Dinitrogen and $\mathrm{N}_{2} \mathrm{O}$ emissions in arable soils: effect of tillage, $\mathrm{N}$ source and soil moisture," Soil Biology and Biochemistry, vol. 39, no. 9, pp. 2362-2370, 2007.

[36] L. Sánchez-Martín, A. Vallejo, J. Dick, and U. M Skiba, “The influence of soluble carbon and fertilizer nitrogen on nitric oxide and nitrous oxide emissions from two contrasting agricultural soils," Soil Biology and Biochemistry, vol. 40, no. 1, pp. 142-151, 2008.

[37] Z. Mu, S. D. Kimura, Y. Toma, and R. Hatano, "Nitrous oxide fluxes from upland soils in central Hokkaido, Japan," Journal of Environmental Sciences, vol. 20, no. 11, pp. 1312-1322, 2008.

[38] B. Liang, J. Lehmann, D. Solomon et al., "Black carbon increases cation exchange capacity in soils," Soil Science Society of America Journal, vol. 70, no. 5, pp. 1719-1730, 2006.

[39] P. Boeckx and O. Van Cleemput, "Estimates of $\mathrm{N}_{2} \mathrm{O}$ and $\mathrm{CH}_{4}$ fluxes from agricultural lands in various regions in Europe," Nutrient Cycling in Agroecosystems, vol. 60, no. 1-3, pp. 35-47, 2001.

[40] J. A. MacDonald, U. Skiba, L. J. Sheppard et al., "The effect of nitrogen deposition and seasonal variability on methane oxidation and nitrous oxide emission rates in an upland spruce plantation and moorland," Atmospheric Environment, vol. 31, no. 22, pp. 3693-3706, 1997.

[41] S. C. Whalen, "Influence of $\mathrm{N}$ and non-N salts on atmospheric methane oxidation by upland boreal forest and tundra soils," Biology and Fertility of Soils, vol. 31, no. 3-4, pp. 279-287, 2000.

[42] J. P. Megonigal and A. B. Guenther, "Methane emissions from upland forest soils and vegetation," Tree Physiology, vol. 28, no. 4, pp. 491-498, 2008.

[43] E. A. Davidson, F. Y. Ishida, and D. C. Nepstad, "Effects of an experimental drought on soil emissions of carbon dioxide, methane, nitrous oxide, and nitric oxide in a moist tropical forest," Global Change Biology, vol. 10, no. 5, pp. 718-730, 2004.

[44] F. L. Wang and J. R. Bettany, "Methane emission from Canadian prairie and forest soils under short term flooding conditions," Nutrient Cycling in Agroecosystems, vol. 49, no. 1-3, pp. 197-202, 1997.

[45] R. Brumme and W. Borken, "Site variation in methane oxidation as affected by atmospheric deposition and type of temperate forest ecosystem," Global Biogeochemical Cycles, vol. 13, no. 2, pp. 493-501, 1999.

[46] A. P. S. Adamsen and G. M. King, "Methane consumption in temperate and subarctic forest soils: rates, vertical zonation, and responses to water and nitrogen," Applied and Environmental Microbiology, vol. 59, no. 2, pp. 485-490, 1993.
[47] M. S. Castro, P. A. Steudler, J. M. Melillo, J. D. Aber, and R. D. Bowden, "Factors controlling atmospheric methane consumption by temperate forest soils," Global Biogeochemical Cycles, vol. 9, no. 1, pp. 1-10, 1995.

[48] B. C. Ball, K. A. Smith, L. Klemedtsson et al., "The influence of soil gas transport properties on methane oxidation in a selection of northern European soils," Journal of Geophysical Research D, vol. 102, no. 19, pp. 23309-23317, 1997.

[49] K. A. Smith, T. Ball, F. Conen, K. E. Dobbie, J. Massheder, and A. Rey, "Exchange of greenhouse gases between soil and atmosphere: interactions of soil physical factors and biological processes," European Journal of Soil Science, vol. 54, no. 4, pp. 779-791, 2003.

[50] H. Feng, G. Cheng, and L. An, "Microbial-mediated methane cycle in soils and global change: a review," Journal of Glaciology and Geocryology, vol. 26, no. 4, pp. 411-419, 2006 (Chinese).

[51] Y. Yan, D. Wang, and J. Zheng, "Advances in effects of biochar on the soil $\mathrm{N}_{2} \mathrm{O}$ and $\mathrm{CH}_{4}$ emissions," Chinese Agricultural Science Bulletin, vol. 29, no. 8, pp. 140-146, 2013 (Chinese).

[52] O. Cetin and L. Bilgel, "Effects of different irrigation methods on shedding and yield of cotton," Agricultural Water Management, vol. 54, no. 1, pp. 1-15, 2002.

[53] N. Dağdelena, H. Başalb, E. Yılmaza, T. Gürbüza, and S. Akçaya, "Different drip irrigation regimes affect cotton yield, water use efficiency and fiber quality in western Turkey," Agricultural Water Management, vol. 96, no. 1, pp. 110-120, 2009.

[54] N. Ibragimov, S. R. Evett, Y. Esanbekov, B. S. Kamilov, L. Mirzaev, and J. P. A. Lamers, "Water use efficiency of irrigated cotton in Uzbekistan under drip and furrow irrigation," Agricultural Water Management, vol. 90, no. 1-2, pp. 112-120, 2007.

[55] C. R. Camp, P. J. Bauer, and P. G. Hunt, "Subsurface drip irrigation lateral spacing and management for cotton in the southeastern Coastal plain," Transactions of the American Society of Agricultural Engineers, vol. 40, no. 4, pp. 993-999, 1997. 


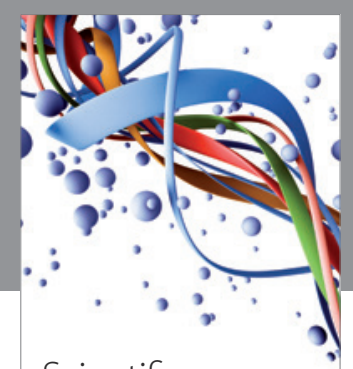

Scientifica
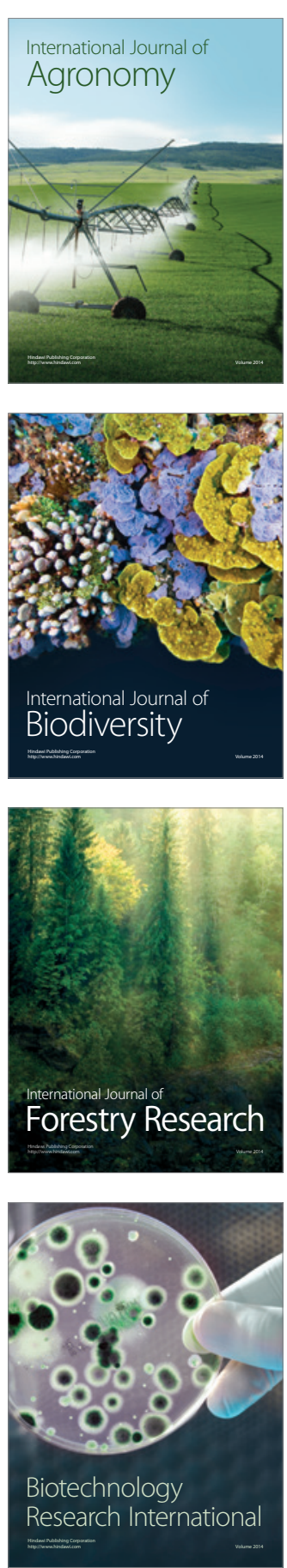
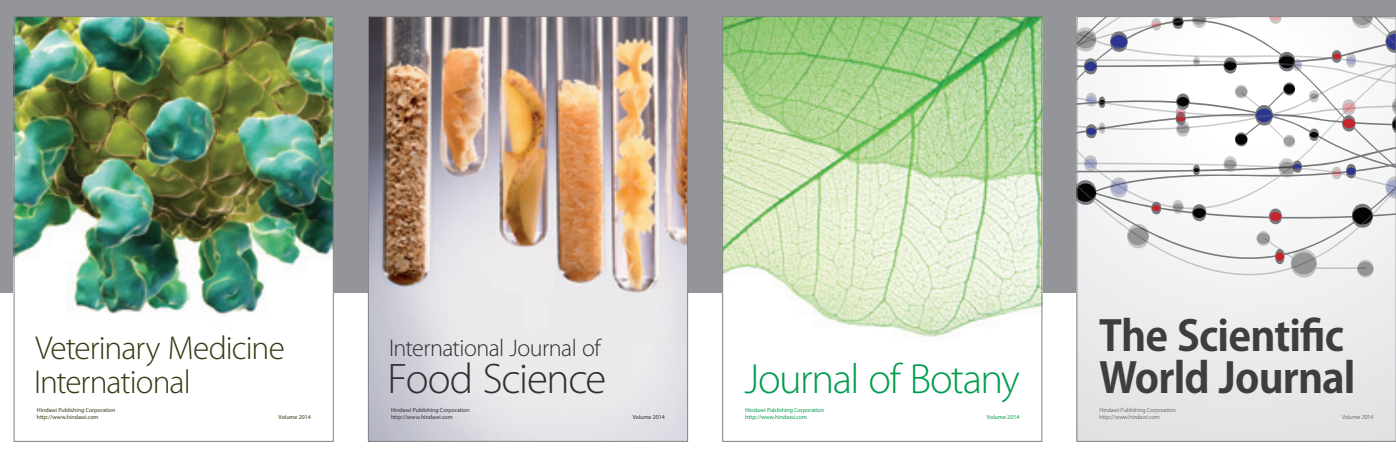

The Scientific World Journal
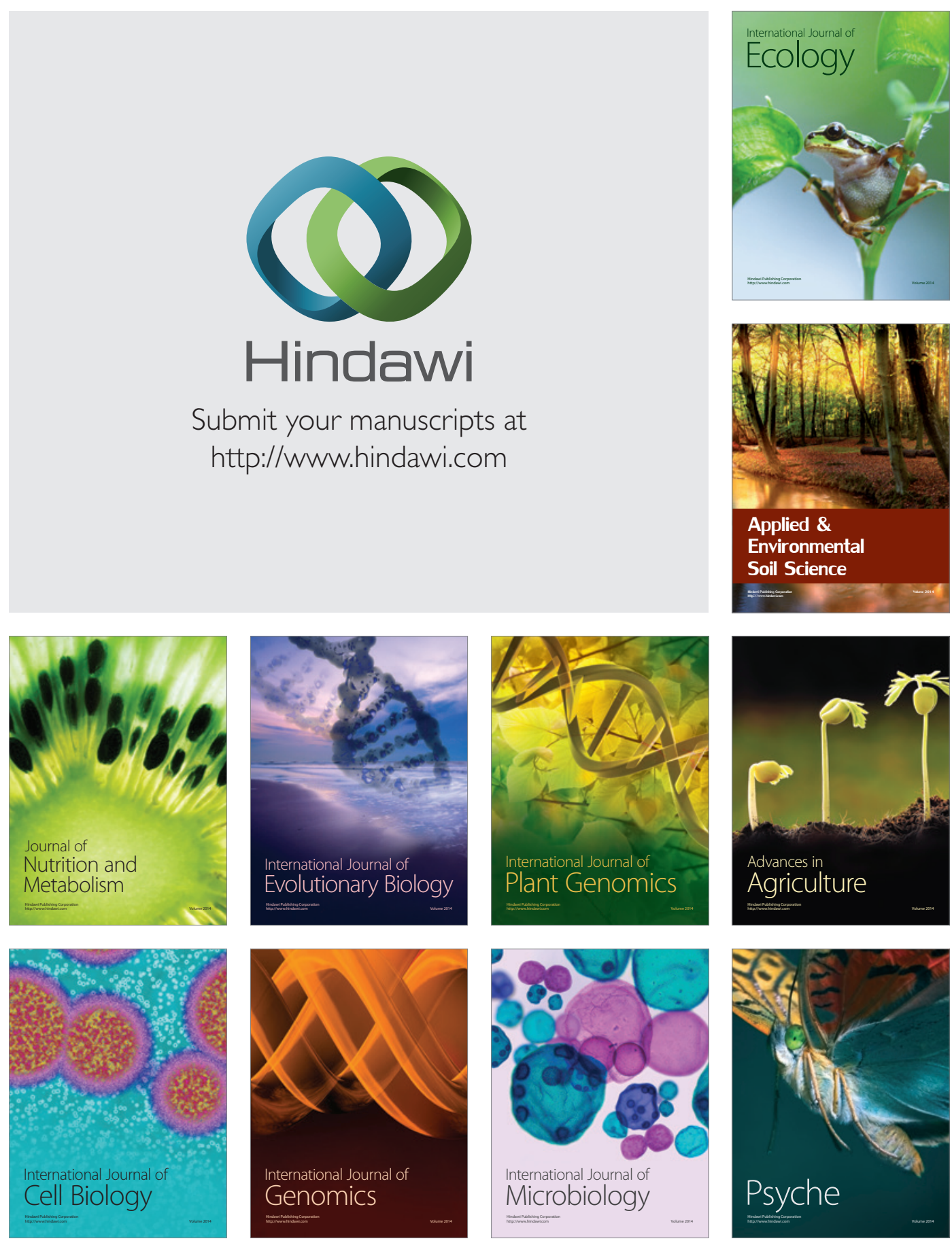